\title{
Máscaras, ficção e mise-en-scène na fotografia contemporânea
} Masks, fiction and mise-en-scène in contemporary photography

\section{AMÉRICA CUPELLO}

Universidade Federal Fluminense (UFF) Niterói, Brasil

\section{RESUMO}

artigo é uma reflexão sobre o uso da máscara na miseen-scène fotográfica, com ênfase no ato de mascarar e suas acepções no repertório fotográfico contemporâneo. Como referência conceitual faço uso da série $\bigcirc$ álbum de família de Lucybelle Crater, de Ralph Eugene Meatyard. Percebo que o autor, precursor da fotografia encenada entre os anos 60 e 70, constrói suas narrativas no limiar entre a realidade e a ficção, trazendo para a atualidade um novo olhar sobre a fotografia, ela própria operando como instrumento da opacidade, ou seja, máscara.

\section{PALAVRAS-CHAVE}

Fołografia, máscara, mise-en-scène, ficção.

\begin{abstract}
A B S T R ACT
The article is a reflection on the use of the mask in photographic mise-en-scène, with emphasis on the act of masking and its meanings in contemporary photographic repertoire. As a conceptual reference I look to the series The Family Album by Lucybelle Crater and Ralph Eugene Meatyard. I realize that the author, the precursor of photography staged between the 60s and 70s, constructs his narratives on the threshold between reality and fiction, bringing to the present time a new challenging look at photography itself, operating through a path of opacity, that is to say, a mask
\end{abstract}

\section{KE YWORDS}

Photography, mask, mise-en-scène, fiction. 


\section{Introdução}

Cobrir, mascarar, criar ruídos, provocações agenciadas pelo fotógrafo, cujas imagens não revelam uma dada realidade; revelam múltiplas camadas de sentido. Ao investigar o diálogo e os atritos entre a fotografia e os artefatos-envoltórios ${ }^{1}$ potencializados na cena a ser fotografada, considerei nessa pesquisa o mascaramento e a máscara, prática lúdica e estratégia teatral, recursos que a fotografia aqui abordada expõe. É por meio dessa irrecusável opacidade inerente a toda e qualquer fotografia que pretendo me aproximar na análise da mise-en-scène que ocorre no domínio da fotografia.

No universo fotográfico, a mise-en-scène perfaz o caminho do artista que elabora com seu olhar criador tanto a concepção como a direção, produção, montagem cênica e pós-produção de narrativas imaginárias, de forte tônus subjetivo, assim como faz um diretor de cinema ou teatro. A diferença na mise-en-scène fotográfica está no fato de o fotógrafo ser o produtor, o diretor, o encenador e, muitas vezes, performer, participando de todas as etapas na construção de suas narrativas e mitologias particulares. Segundo Fernandes (2009, p. 158),

A fotografia encenada (staged photography, tableau narratif ou tableau vivant) tem raízes na história da fotografia e traz como principal alteração o conceito de direção da fotografia, que deixa de lado o mundo "real" para penetrar no reino da imaginação - mundos fantasiosos, oníricos, fictícios e até mesmo uma visão pessoal -, produzido unicamente com a finalidade de ser fotografado.

Cabe ressaltar que à fotografia encenada presente desde o final dos anos 60, e cujo auge se deu nos anos 80 e 90, vêm somar-se artistas que trabalham com manipulações no próprio suporte, ou seja, procedimentos cujas raízes históricas remontam às vanguardas artísticas dos anos 20 e 30. Essas manipulações e experiências dos artistas repercutem numa performance particular, aquela que permeia as relações entre o artista e a obra, possibilitando expansões gestuais e espaciais. A arte da performance reaparece nesse contexto como fio condutor de novas possibilidades na relação obra/artista. Ações e relações que remetem a um diálogo segundo Sobrinho (2005, p. 89): "É interessante ressaltar que os artistas plásticos, ao realizarem suas experiências com novos materiais e suportes, buscavam uma espécie de ‘diálogo com os materiais'”. Observa ainda o autor que "esta relação coincide com a postura de performers quando estão em situação cênica". A teatralidade nesse processo provém da atitude iconoclasta do artista que experimenta com o suporte fotográfico, como podemos verificar nas experiências² realizadas por Man Ray e MoholyNagy, por exemplo. Reconheço essa atitude como própria do performer. É importante notar a

1 Denomino artefatos-envoltórios aqueles que envolvem os modelos ou pessoas fotografadas: vestes, máscaras e décor utilizados na mise-en-scène fotográfica.

2 Me refiro as experiências desses artistas, que de forma pioneira, produziram fotogramas com o uso de objetos e fontes de luz "em movimento" sobre o papel fotográfico, mudando o teor documental dessa técnica, para outro, de natureza criativa e experimental. 
construção da cena a partir da câmera - pois a câmera pode ser pensada como uma espécie de máscara, que permite ritualizar um gesto (o gesto fotográfico) e por meio desse gesto acessar uma outra dimensão: a da imagem fotográfica.

O fotógrafo Ralph Eugene Meatyard destaca-se no panorama da fotografia americana dos anos 60 como um dos precursores da fotografia encenada, assim como Duane Michals, Les Krims, Bernard Faucon, entre outros, operando a partir da câmera. No Brasil aponto Boris Kossoy, historiador e fotógrafo, especialmente seu livro "Viagem pelo fantástico", 3 de 1971, exemplo da fotografia encenada que aqui começava a despontar.

Optometrista por profissão, Ralph Eugene Meatyard iniciou-se na fotografia ao desejar fotografar sua família: a esposa e os três filhos. Desde o princípio, seu olhar paradoxal focalizou os desfoques, a ficção, a encenação transformando o que seriam simples registros de família, alterados pela camada fictícia que ele agrega ao colocar máscaras nos familiares fotografados, fazendo de registros que seriam de âmbito puramente pessoal questões universais e inquietantes. Esse posicionamento singular na época (anos 60) se opunha a uma fotografia modernista que proclamava a potência da imagem como documento e afirmação do real. Meatyard não se interessava pela realidade das ruas, a chamada street photography, como era comum à maioria dos fotógrafos. Interessava-se, no entanto, por outra realidade, a que emerge das narrativas e ficções provenientes de seu universo interior. O que move sua obra é a arte da câmera, os desfoques e alterações que o fotógrafo promove no próprio ato de fotografar.

Cabe lembrar que, na transição da fotografia moderna para a pós-moderna, Meatyard habitou um terreno limiar. A questão da máscara e o uso que fazia da iluminação, com imagens banhadas em sombras e penumbra, estética utilizada na maioria de suas imagens, foram interpretadas de forma inadequada devido às circunstâncias de sua biografia, que remete a sua morte prematura. 4

É importante notar o uso teatral da máscara, artefato que o autor aborda com o sentido de película a ser transposta; um véu em movimento interposto na cena fotográfica, como marca de uma passagem, de um devir.

A obra de Meatyard, especialmente a série 0 álbum de Família de Lucybelle Crater deixa à tona a ambivalência entre as instâncias documentais e ficcionais da narrativa fotográfica.

3 "Constitui uma obra autoral pioneira em termos de Brasil e América Latina. Contudo, suas criações são simbólicas, iam na contramão do tradicional emprego convencional da fotografia enquanto instrumento de registro destinado a aplicações imediatas, ilustrativas ao mesmo tempo em que punham em xeque a 'fotografia artística' dos fotos clubes" (KOSSOY, s.d.).

4 Uma semana antes de completar 47 anos Ralph Eugene Meatyard morreu em decorrência de um câncer terminal. Acredito que esse fato tenha influenciado um tipo de leitura de sua obra que sugere, no caso da série $O$ álbum de família de Lucybelle Crater e suas demais ficções com personagens mascaradas, o uso de máscaras como uma descida ao território do horror e das sombras. Em vez disso, porém, sua obra almeja uma circularidade vital, abrangendo o fim, mas também o início, que ele revela nessa série, como um potente vir a ser, um devir. Neste estudo me refiro ao laboratório fotográfico analógico; mas é importante observar essa técnica de "mascarar" as cópias fotográficas e os originais fazendo uso de procedimentos específicos ao laboratório digital. 
Ambivalência que sempre existiu desde os primórdios da técnica, ao aproximar-se da ficção e do teatro. O autor traz a inquietação da opacidade em contraposição a uma questionável transparência documental, muitas vezes ligada à imagem fotográfica. Rouillé (2009, p. 279) ilumina essa questão:

Ao contrário do pictorialismo, que opacificava as provas com intervenções manuais, a fotografia criadora opera mudando a visão, ou, pelo menos, reavaliando aquilo que a luz e a óptica geométrica escondem da fotografia: sua maneira de representar as coisas como espectros de um teatro de sombras. Tratase, na verdade, de passar a fotografia da luz para a sombra, da transparência para a opacidade, da nitidez das linhas geométricas para o flou das superfícies espectrais, da soberania do olho para a sensualidade tátil das matérias, das descrições racionais para as ilusões e as ficções.

Destaco neste estudo os valores narrativos da fotografia encenada e suas aproximações e contaminações com outras linguagens, especialmente as artes com mais tradição ficcional, como a literatura e o teatro. Nesse sentido vejo a fotografia como um espaço propício a mise-en-scène, dentro do qual posso abordar teatralidade: máscara, gesto e ficção.

\section{Acepções da máscara e usos no repertório fotográfico}

Cabe esclarecer os usos do vocábulo "máscara" no repertório fotográfico acessado neste estudo, bem como o uso que faço do ato de mascarar quando operado no sistema fotografia e em sua encenação. Abordo os sentidos de máscara de forma polissêmica a partir dos variados procedimentos verificados no laboratório fotográfico .5 Nesse sentido, máscara ou o fato de mascarar é um bloqueio literal de uma área que não quero imprimir ou a construção de áreas opacas e obstrutivas à luz, com a função de bloquear a luminosidade proveniente do ampliador fotográfico. Máscara também pode referir pequenos artefatos elaborados para funcionar como bloqueadores de luz na ampliação da cópia fotográfica.

A fotógrafa Lilian Bassman (Figura 1) utilizou essa técnica como um estilo próprio na cópia criativa realizada em preto e branco. Suas figuras, totalmente redesenhadas pelo uso de máscaras que fabrica para aplicação no laboratório fotográfico, revelam seu estilo único, que permeia a cópia fotográfica entre os domínios do desenho e da fotografia. Seu procedimento consiste em construir máscaras com pequenos orifícios, para que a impressão da luz se faça de forma absolutamente lenta. Enquanto uma cópia-padrão leva poucos minutos para ser impressa no suporte fotossensível do papel fotográfico, suas cópias são produzidas em outro patamar, cada cópia consumindo horas para ser finalizada.

5 Neste estudo me refiro ao laboratório fotográfico analógico; mas é importante observar essa técnica de "mascarar" as cópias fotográficas e os originais fazendo uso de procedimentos específicos ao laboratório digital. 


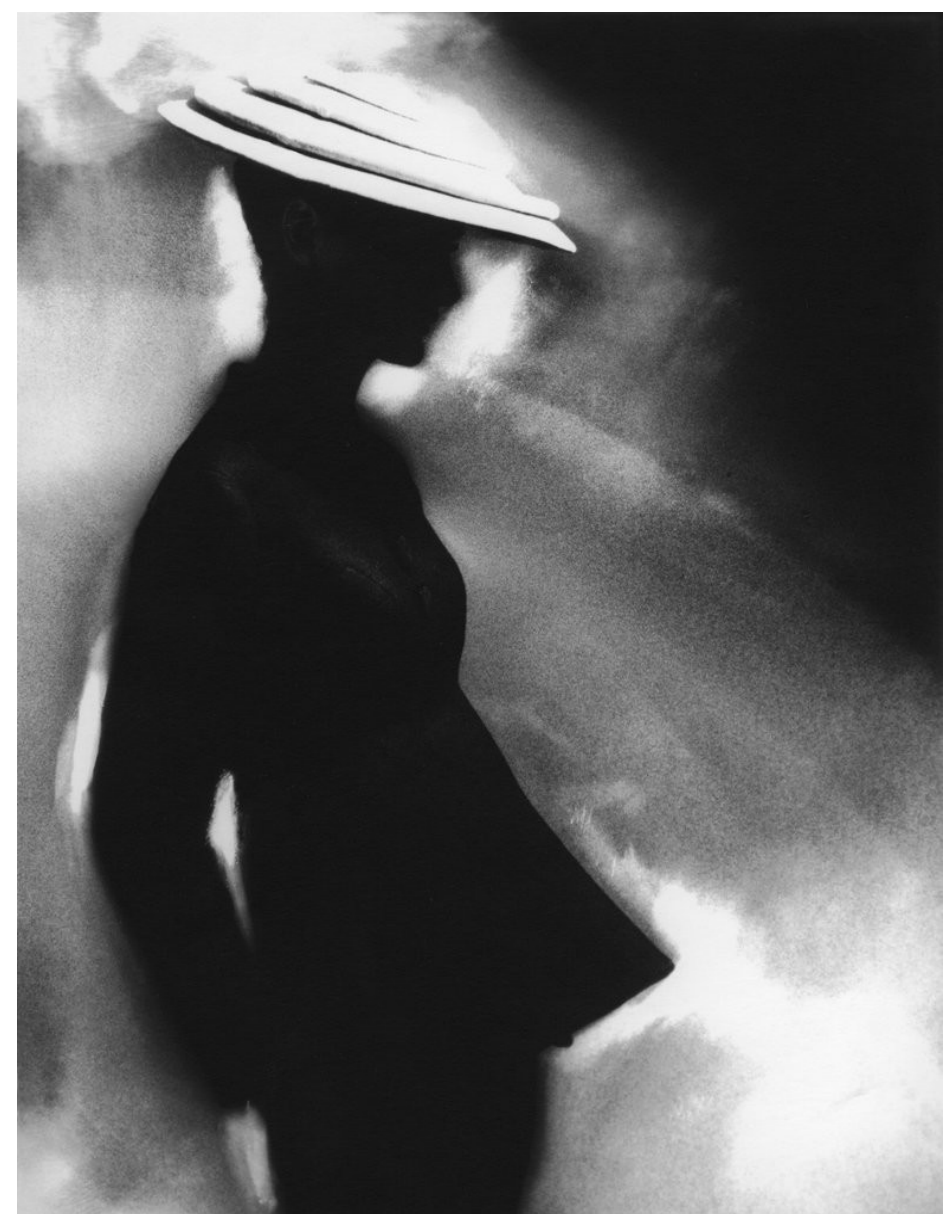

Figura 1. Lilian Bassman, 1955-1994, Tunic Suit. Fotografia PB. Fonte: Chermayeff, 1997.

Máscara nesses parâmetros significa técnica de obstrução da luz no suporte fotossensível do papel, mas na técnica da fotomontagem também designa obstrução e construção em camadas, por meio de aplicação de películas e volumetrias no suporte fotográfico. Essas películas obstrutivas atuam como espécies de velamentos. Trata-se de "colocar o véu na imagem", obstruir a passagem da luz. Lemagny (apud Rouillé, 2009, p. 280) afirma que o "corpo da fotografia é a sombra" e que, em "última análise, uma foto é constituída, do princípio ao fim, pelos valores táteis de suas sombras".

Trata-se da instalação de uma nova forma de abordar a imagem, no movimento de sua construção fazendo uso desse operar em máscara, ou seja, operar privilegiando a oclusão. Esse tipo de construção, quando se dá no suporte fotográfico pode ser relacionado à temporalidade que abarca "o ver e ao mesmo tempo o não-ver" (o piscar dos olhos) proporcionado pelas técnicas da fotomontagem, o que é percebido por Lissovsky (2008, p. 150-151) comentando as técnicas das vanguardas: 
A piscada de olhos foi um motivo (e também uma "teoria") particularmente relevante para as vanguardas históricas dos anos 1920 e 1930 [...]. Para os surrealistas, fechar os olhos, piscar diante do que se vê, podia representar a condição de fazer advir o inconsciente, projetando-o sobre o que se via. Essa é uma das chaves para uso frequente de recursos como colagens, montagens, exposições múltiplas.

Esses sentidos de máscara verificados nos potenciais que reverberam do laboratório fotográfico e das ações diretas do artista no suporte demandam a abertura de parênteses para refletir sobre o uso da máscara e seu rico potencial de obstrução e envelopamento, que se revela também a partir do interior da cena fotografada. Relaciono o sentido de uma figura que usa máscara e o valor da instauração da persona, 6 daquele que porta máscara. É o que analiso na obra de Meatyard.

Quando me refiro à cena fotográfica, a máscara pode operar como um disfarce, uma personagem que a use visando tornar-se indiferenciado ou anônimo. Partícipe do jogo teatral, a máscara permite que se coloquem em cena personae e construções oferecidas ao olhar na instigante oscilação entre os atos de simular e dissimular. ${ }^{7}$ Dessa forma aciona-se uma espécie de teatralidade que prescreve o "não ser" e a instauração de personae como estratégia visual ambígua. Foi o que percebeu Meatyard ao sensibilizar as instâncias não visíveis da fotografia com o uso criativo do mascaramento no interior da cena fotografada, em sua proposta, que revela a própria fotografia como potência de opacidade. Segundo Dubois (1993, p. 326),

A foto? Não acreditar (demais) no que se vê. Saber não ver o que se exibe (e que se oculta). E saber ver além, ao lado, através. Procurar o negativo no positivo, e a imagem latente no fundo do negativo. Ascender da consciência da imagem rumo à inconsciência do pensamento. Refazer de novo o caminho do aparelho psíquicofotográfico, sem fim. Atravessar as camadas, os extratos, como o arqueólogo. Uma foto não passa de uma superfície. Não tem profundidade, mas uma densidade fantástica. Uma foto sempre esconde outra, atrás dela, sob ela, em torno dela. Questão de tela. Palimpsesto.

Refiro-me ao uso da máscara no sentido de Ralph Eugene Meatyard, como película, camada entre opaca e transparente a ser transposta. No âmbito de sua poética, na qual a máscara é um elemento primordial, verifico ainda o uso do familiar tornado estranho; a duplicação da fixidez fotográfica, ou seja, a indiferenciação observada no uso da máscara não pretende o anonimato, mas a possibilidade de identificação ao se deixar a figura com máscara ser, de acordo com o fotógrafo, "o aroma de uma pessoa; não uma pessoa em particular". É Meatyard (apud Rhem, 2002, p. 40) que explica quando a ideia de usar máscaras the apareceu pela primeira vez:

6 Persona, -ae, em latim, máscara, personagem, papel, caráter, indivíduo, pessoa (PERSONA, 2008-2020).

7 No sentido que coloca Baudrillard (1991, p. 9), “dissimular é fingir não ter o que se tem. Simular é fingir ter o que não se tem". 
Suponho que isso começou num seminário organizado por Henry Smith em Indiana em 1956. A ideia de uma pessoa é totalmente diferente, digamos, numa fotografia que mostra uma menininha com o título "Rose Taylor", numa com o título "Rose" ou ainda numa sem título. "Rose Taylor" indica uma pessoa específica quer você a conheça ou não. "Rose" é mais generalizante e pode ser uma de muitas Roses, muitas pessoas. Nenhum título, sugere qualquer um. E a máscara é uma forma de não personalizar uma pessoa (tradução nossa). ${ }^{8}$

A partir do contexto teatral, Simões (2005, p. 143) observa que "Tudo que o ator usa para interpretar é máscara, a personagem é uma máscara, o figurino, a maquiagem”. Nesse sentido, é importante ressaltar a presença dos artefatos-envoltórios que o fotógrafo encenador utiliza no âmbito de sua construção cênica. Entre eles encontro vestes, máscaras e bonecos. Estes últimos funcionam como máscaras de corpo inteiro, uma velatura total. Segundo Amaral (2005, p. 23), "É preciso refletir sobre o uso desses simulacros". Para entender um pouco mais dessa fotografia que encena a finitude por meio do simulacro (refiro-me ao uso de manequins, bonecos e máscaras na cena fotográfica), relaciono o gesto fotográfico ao gesto teatral, percebendo uma aproximação que tanto Barthes (2012) quanto Sontag (1981) já haviam intuído, cada qual a seu tempo.

A própria câmera fotográfica pode ser compreendida como máscara, sentido que trago via enunciação de Omar (2000, p. 13):

Provavelmente a máquina fotográfica é uma espécie de máscara, como aquelas do carnaval de antigamente. As pessoas usavam máscara negra. Até hoje, eu tenho fascinação por essas máscaras. Possuo uma coleção, é uma das minhas favoritas. A câmara fotográfica talvez seja como uma máscara negra. Vai colada ao rosto.

Não se trata, como diz o próprio Omar, de fotografar com um disfarce, ou secretamente; o fotográfo é antes um exibicionista. Há, segundo o autor, uma atitude física de fotógrafo, e essa atitude é uma atitude de presença, de interação. Com o uso das câmeras digitais e smartphones, temos na atualidade outros gestos e questões que ressaltam do registro das representações de si. O fenômeno global das selfies ${ }^{9}$ revela o desejo de incorporar, por meio das máscaras obtidas em aplicativos de imagem, personagens voláteis e descartáveis, e reproduzidas de forma efêmera. Como exemplo cito a fotógrafa Cindy Sherman (s.d.) que tanto experimentou a fotografia de mise-en-scène mediante a criação de inúmeras personagens, diversos gêneros e clichês quanto atualmente experimenta a selfie, compartilhando seus resultados em sua conta no Instagram.

8 No original: I guess it originated in a seminar Henry Smith organized in 1956 up in Indiana. The idea of a person, a photograph say of a young girl with a title "Rose Taylor" or the title "Rose" or no title at all becomes an entirely different thing. "Rose Taylor" is a specific person whether you know her or not. "Rose" is more generalized and could be one of many Roses, many people. No title, it could be anybody. And a mask serves as non-personalizing a person.

9 Fotografia feita com smartphones. 


\section{As máscaras em Lucybelle Crater}

Acompanho a aventura e a movimentação da personagem central da série The family album of Lucybelle Crater (1970-1972), de Ralph Eugene Meatyard, percebendo as sutis camadas e películas, ora opacas, ora transparentes, que se interpõem entre a personagem do álbum, Lucybelle, e o espectador.

Ao conceber essa obra no formato de um “álbum 10 de família” Meatyard produz um registro sutil, que oscila entre o real (sua família, vizinhos e círculo de amigos) e o ficcional (as máscaras). Lucybelle Crater é a personagem principal representada por uma bizarra máscara que retrata uma mulher, velha ou bruxa, 11 totalmente opaca. As fotografias desse álbum são legendadas no estilo de um antigo álbum de família. Segundo Rhem (2002, p. 12), “A catalogação, a estética do álbum como Meatyard propõe, com seus momentos formais de posar, ecoa não exatamente os álbuns de instantâneos [snapshots] dos anos 60 ou 70, mas aproxima-se da estética dos álbuns de retratos de uma época anterior." (tradução nossa) ${ }^{12}$ Numa leitura inicial, as máscaras se impõem em primeiro plano, causando estranheza. Como consequência do olhar que a máscara atrai, o espectador pode ficar preso ao poder "medusante" da máscara opaca de Lucybelle, não se dando conta das demais camadas de sentido que o álbum oferece. Pouco a pouco, porém, devido sobretudo ao formato seriado, a inquietação do grotesco que a máscara provoca, principalmente a de Lucybelle, vaise diluindo. Dessa forma, a repetição torna comum o não familiar à medida que se acompanha a evolução das 64 imagens desse álbum.

É preciso entender a relação entre imagem e referente proposta pelo artista. Relação essa que é problematizada por meio dos matizes da máscara. Operando como película que reverbera do interior da cena fotográfica, a máscara é a intermediação alegórica - o próprio ruído entre o espectador e a imagem. Meatyard propõe, com suas máscaras, uma estratégia ambígua, que ora oculta, ora revela. De forma simulada, ou seja, assumindo a persona Lucybelle, o autor exibe e protagoniza um mascaramento, a partir do diálogo visual proposto na cena fotografada.

Tomando como ponto de partida a estrutura do álbum, temos duas pessoas, duas máscaras e um fundo nítido para cada quadro. Temos também imagem mais legenda na estrutura narrativa do álbum: legendas como falas, como estrofes que se voltam sobre si mesmas. Na sequência que compreende 64 páginas de imagens sucessivas, encontra-se, antes da última imagem, uma foto sem legenda, como um silenciar narrativo, funcionando como uma pausa que dramatiza, como no andamento de uma melodia.

10 Segundo Rouillé (2009, p. 187), "De fato, o álbum entrecruza três modos de expressão: as imagens, as legendas (muitas vezes manuscritas) e a sucessão narrativa das imagens. Através desse dispositivo, um sujeito fala e se exprime, manifesta seus desejos e suas crenças, e assim contribui para construir uma ficção da família. O sujeito que fotografa não é necessariamente aquele que confecciona o álbum, mas as ações tanto de um quanto de outro convergem para um objeto que mistura o visível e o enunciável, que emana da família, mas que não a representa. Pois, entre as situações e as pessoas, de um lado, e as imagens, as legendas, o álbum, do outro - isto é, entre as coisas e os sinais -, as relações não se reduzem à representação.

11 É interessante notar a palavra bruxa em inglês (witch) que, segundo Estés (1995, p. 122), deriva do termo "wit", que significa sábio.

12 No original: The cataloging, album aesthetic as Meatyard uses it, with its formal moment of posing, echoes, not the snapshot albums of the 1960s and 1970s, but the portrait-album aesthetic of an earlier era. 


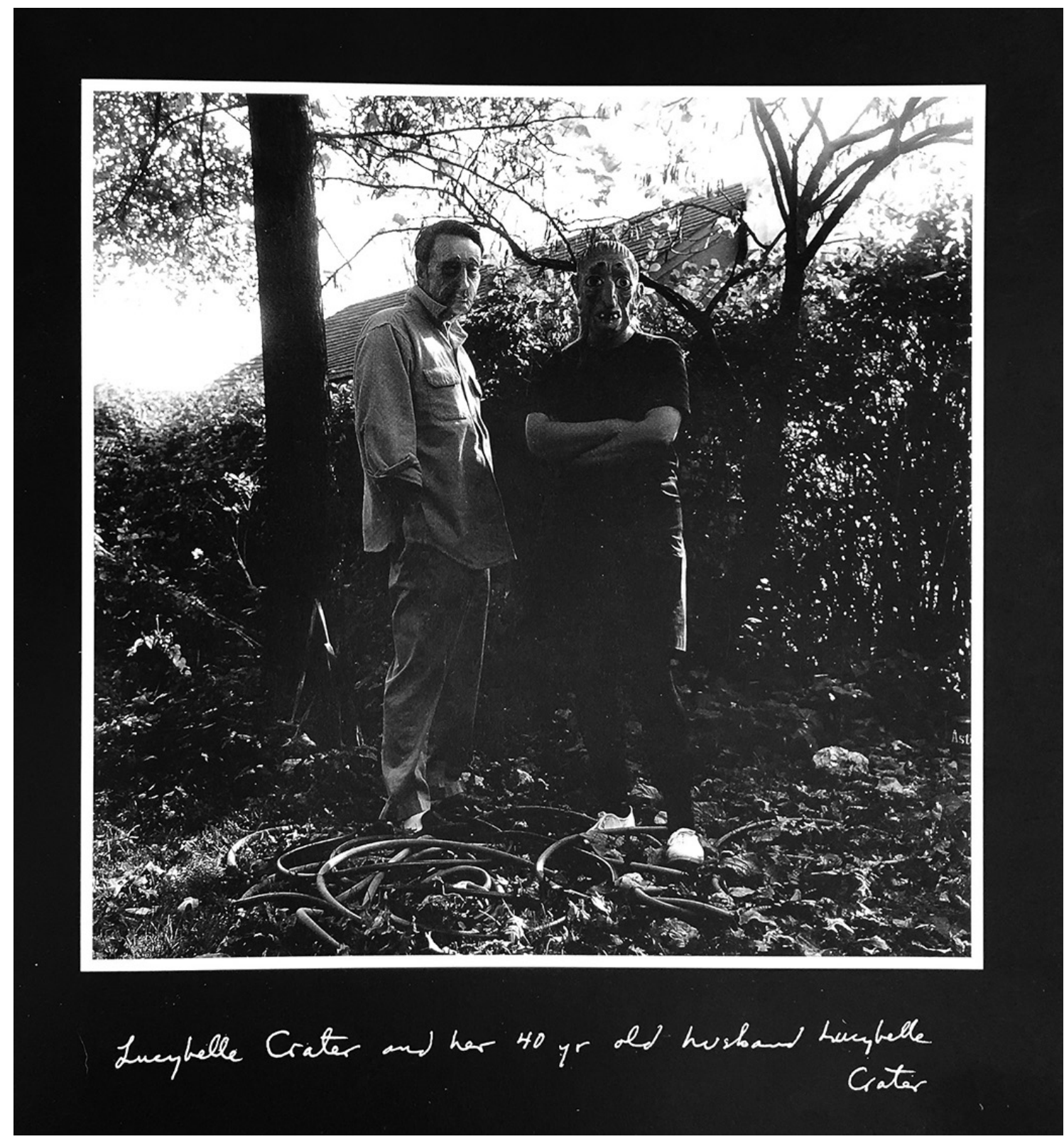

Figura 2. Ralph Eugene Meatyard, 1970-1972, The family album of Lucybelle Crater, (primeira imagem do álbum). Fonte: Rhem, 2002.

A última imagem do álbum (Figura 3) remete à primeira (Figura 2), mas com as personagens invertidas. Madelyn, esposa de Meatyard, interpreta Lucybelle em todas as imagens, exceto na última, em que o próprio Meatyard adota a persona de Lucybelle e assume sua identidade.

Das máscaras surgem as questões relativas a diferenças entre anonimato, identidade e particularidade que operam no âmbito do que está escondido, oculto nos retratados, principalmente a estratégia de não particularizar uma pessoa em especial, o que as máscaras fazem com maestria. 


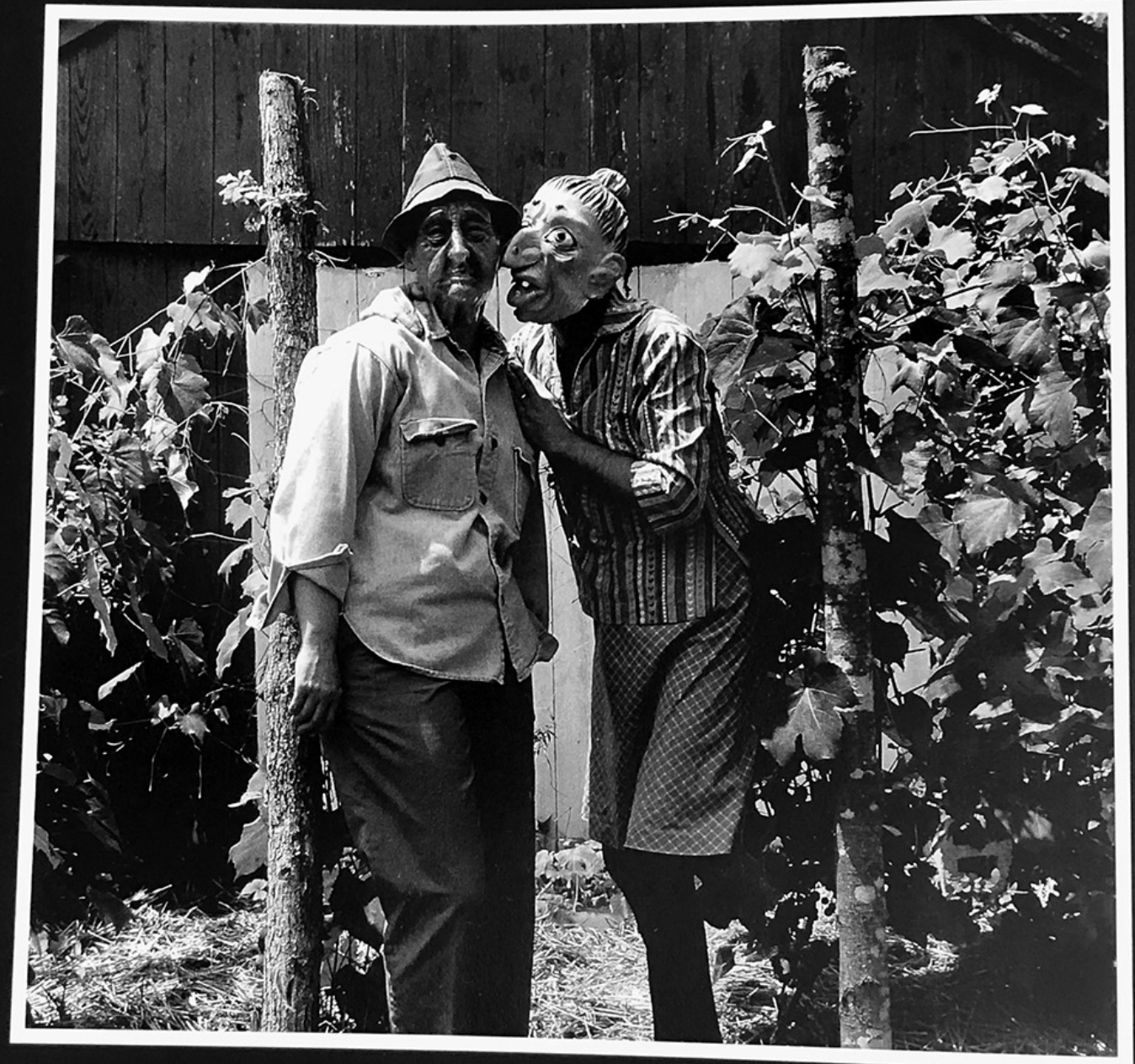

$$
\begin{aligned}
& \text { Lecybelle Crater and close Friend Lucybelle } \\
& \text { Crater in the grape arbor }
\end{aligned}
$$

Figura 3. Ralph Eugene Meatyard, 1970-1972, The family album of Lucybelle Crater, (última imagem do álbum). Fonte: Rhem, 2002.

Quando opera com as máscaras na série Lucybelle, Meatyard propõe ao espectador algo além de um simples olhar. Promove a função catártica e mágica desse artefato revelando os outros que nos habitam, o anônimo, as personagens. Seu jogo teatral opera com a inquietação instaurada entre, autor, personagem e máscara, mesclando nessa complexa intermediação a apropriação irônica de um "falso" naturalismo que permeia o repertório histórico dos álbuns de família. 


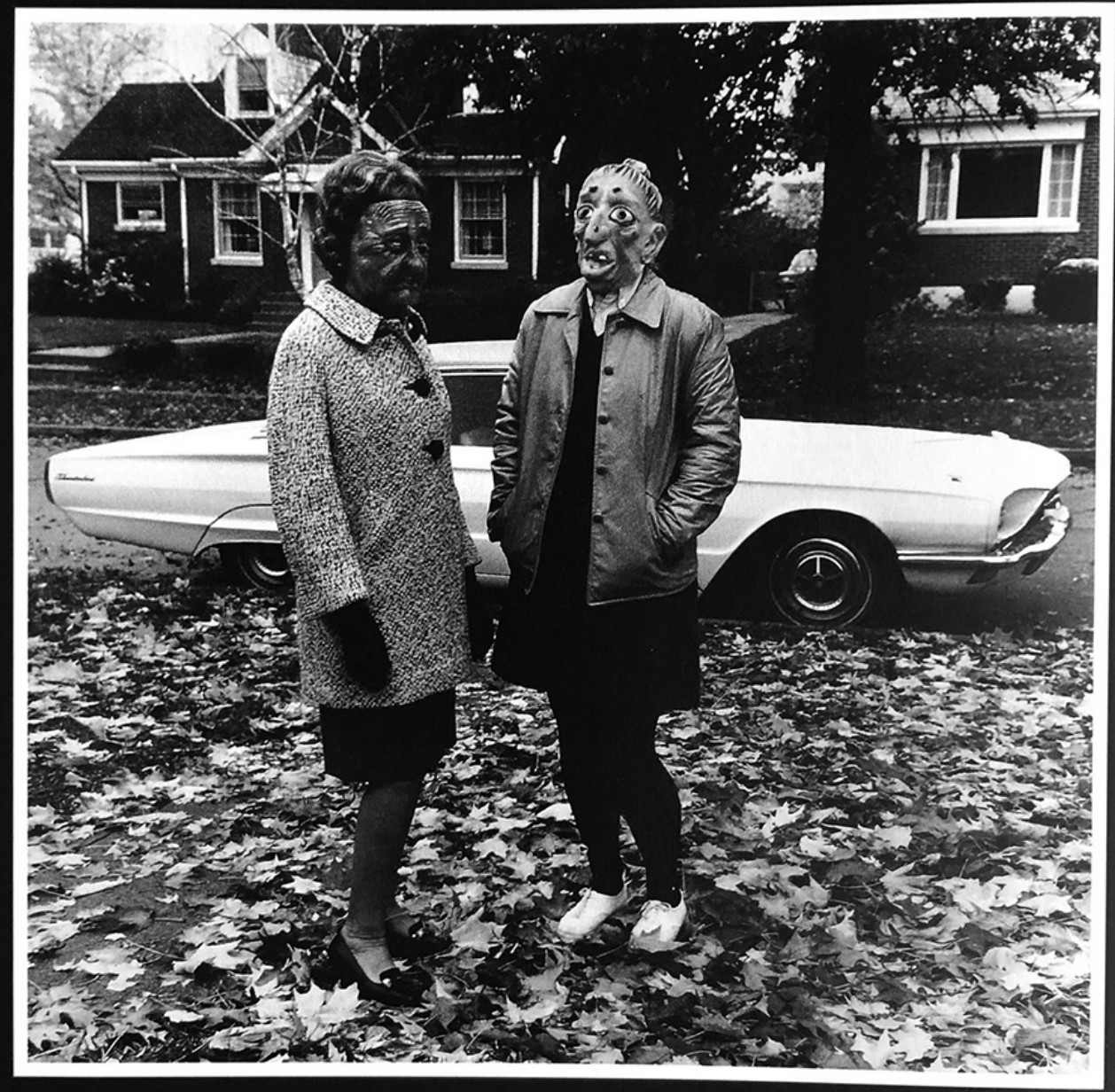

$$
\begin{aligned}
& \text { Lucybelle Crater ot her charmingly youthpul } \\
& \text { mother-in-law, Lueybelle Crater }
\end{aligned}
$$

Figura 4. Ralph Eugene Meatyard, 1970-1972, The family album of Lucybelle Crate,. Fonte: Rhem, 2002.

É importante notar que Meatyard elege as máscaras como oclusão, porém permite o acesso a quem se aventurar a ultrapassar as várias camadas que o álbum em sua narrativa propõe. Assim como a fotografia nunca é somente o que se vê. Meatyard pretende que sejam os espectadores a desfolhar as camadas, a adentrar a superfície densa do fotográfico. Assim como a família universal é a pedra de toque de muitas de suas imagens, a fotografia representava para ele muito mais do que uma simples técnica. Explorando o que definia como o "teatro interior da imaginação" (RHEM, 2009, p. 13), considerava o fotógrafo ator e a fotografia teatro possível. 


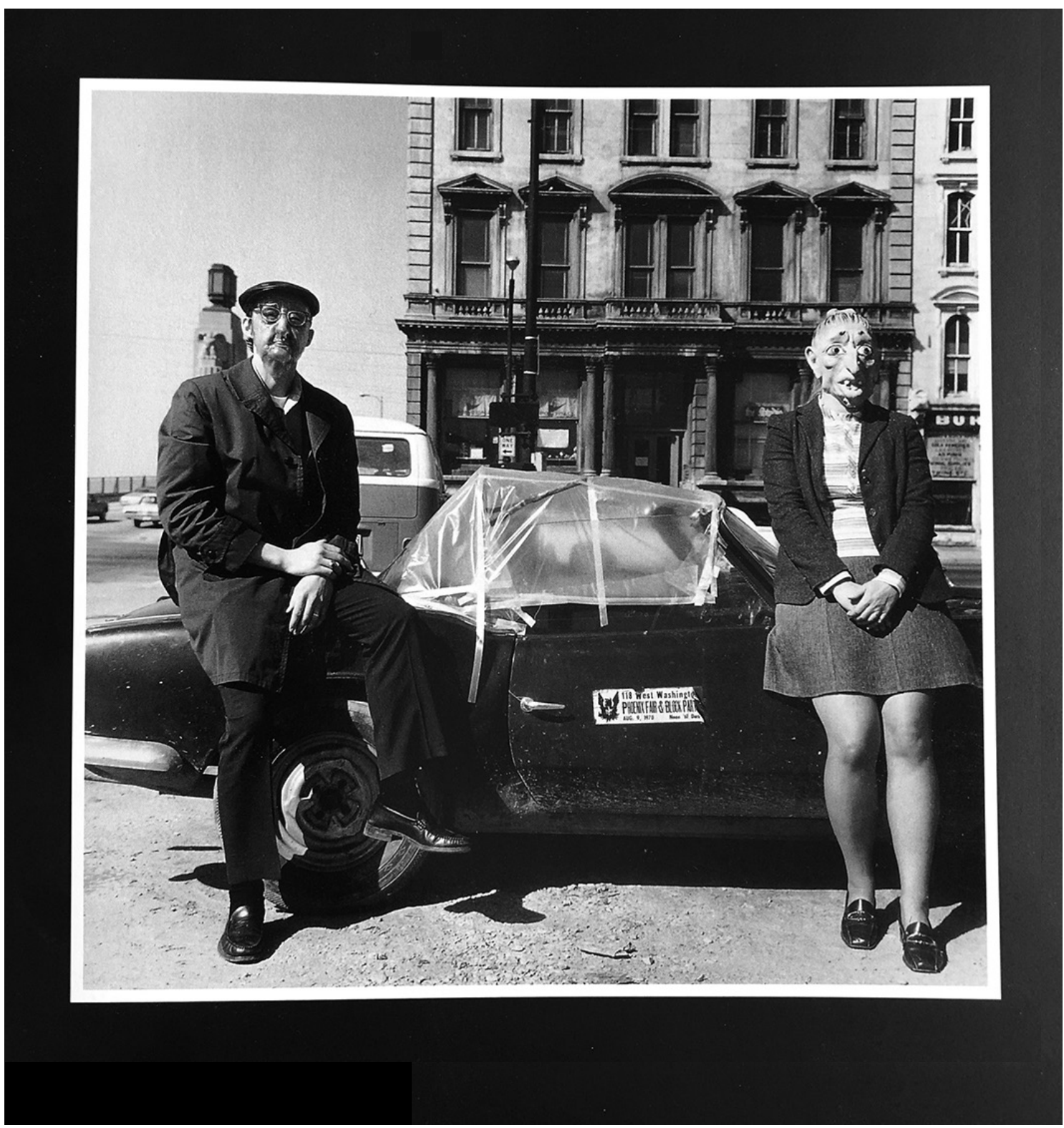

Figura 5. Ralph Eugene Meatyard, 1970-1972, The family album of Lucybelle Crater. Fonte: Rhem, 2002.

Toda a manipulação e o uso de cenários e ficções ocorriam no momento do ato fotográfico. O efeito teatral que o fotógrafo buscava estava no poder inerente da câmera, mesmo quando trabalhava com dupla exposição, foco seletivo e outras técnicas experimentais.

Percebo como Meatyard orquestrou a série The family album of Lucybelle Crater partindo da ideia de "um poema" como ele próprio afirmou. Na raiz desse poema fotográfico, Meatyard, amante da literatura e, em especial, da poesia, apropria-se da poética com base em ênfases (não repetições) encontradas na literatura de Gertrude Stein. 
Evocando a literatura de Gertrude Stein em seu conceito de ênfase, Meatyard leva a cabo a premissa da autora em seu livro The making of Americans (STEIN, citada em Rhem, 2002, p. 41) e comenta: "O caráter completo dos indivíduos não (está) refletido nas palavras e pensamentos [...] mas no MOVIMENTO das palavras e dos pensamentos, eternamente o mesmo, eternamente diferente" (tradução nossa). ${ }^{13}$ Esse jogo de camadas, ora opacas e ora transparentes, é antevisto nas referências e pistas que o fotógrafo revela a respeito do álbum. É possível penetrar e entrever as camadas conforme haja empenho do observador para obter as revelações, sabendo ver além da máscara e das personagens, como nos indica Meatyard. Importantes, porém, são as referências, as camadas de significados que o autor constrói e que se podem entrever se houver mais concentração no movimento de Lucybelle ao longo do álbum. Intui-se que o movimento ultrapassa a fixidez da máscara - sempre a mesma, mas, importante observar, como diz Stein, sempre diferente.

Esse movimento encontra-se na personagem e na estrutura do álbum, ou seja, no padrão que Meatyard escolhe operar: imagens mais legendas, configurando uma estrutura narrativa dinâmica dentro do processo evolutivo do álbum, como num movimento especular. Antes de chegar ao fim, na última fotografia do álbum, intui-se que ele se volta sobre si mesmo, em movimento circular que remete à primeira fotografia, como no encontro de dois espelhos que se miram, o infinito dos espelhos mise en abyme. Estratégia que evoca o fim no início, a ideia de um moto contínuo: a percepção da vida que continua nas imagens do álbum, ao estilo de Stein, "sempre a mesma, sempre diferente". O movimento de Lucybelle ao longo do álbum possui um sentido arborescente: à medida que Lucybelle se movimenta em sentido crescente, de certa forma evolutivo, do núcleo familiar aos pequenos grupamentos vizinhos, expandindo-se para o mundo intelectual, fotográfico e urbano, prioriza a natureza como força propulsora e motor que regem a primeira e a última foto do ensaio, mas também como set preferido dessa ficção e característica marcante na fotografia de Meatyard. O set, ou ambiência urbana, inicia-se abruptamente nas fotografias 62 e 63 . Essas duas ambiências urbanas possuem outra característica, principalmente na fotografia 63 (Figura 5), a única sem legenda e a penúltima da série. Nessa espécie de silêncio, de marcação que antecipa a última imagem, percebe-se entre as duas personagens principais, a carroceria de um carro com os vidros quebrados e substituídos por uma película plástica com remendos, como uma terceira máscara na cena.

O silenciar da legenda e a película semitransparente improvisada no veículo marcam um compasso pungente, um ritmo surdo para anunciar a entrada final da personagem. Na última imagem do álbum "O casal e Lucybelle", ou Lucybelle-Meatyard mais sua esposa, Madelyn, retornam ao jardim primordial como na primeira imagem. Invertidos os papéis, Meatyard veste a máscara de Lucybelle, e sua esposa, as roupas e a máscara semitransparente do marido. Meatyard e Lucybelle, autor e personagem juntos na árvore da vinha, símbolo dessa derradeira imagem. É importante notar a presença duplicada da árvore da vinha: tanto na imagem como na legenda,

13 No original: "...the complete characters of individuals [are] refleted not in the words and thoughts...but in the MOVEMENT of words and thoughts, endlessly the same and endlessy different". 
portanto, dupla ênfase. Meatyard realiza uma experiência de teatro, percebendo de forma genial a fixidez da fotografia, como mais um nível, mais uma camada nesse seu poema conceitual, em que é preciso ultrapassar as aparências para se chegar à imagem poética, à imaginação.

Em relação à estrutura do álbum é importante ressaltar o valor das palavras (as legendas) junto às imagens. Segundo Meatyard (apud Rhem, 2002, p. 40) "as palavras são imagens". No campo semântico de Lucybelle são estas estruturas binárias (imagens + legendas) que marcam um ritmo, uma espécie de estrofe especular que enfatiza um movimento circular. 0 fim é o início, e o início pode ser o fim. Essa gramática, fortemente influenciada pelo ritmo musical, revela a música e a poesia como grandes interesses ${ }^{14}$ de Meatyard na época em que produziu essa série fotográfica. Rhem (2002, p. 41) destaca a sonoridade do nome Lucybelle; nele há referência a uma personagem de Flannery O'Connor (2008, p. 230), Lucynell Crater. A mudança parece indicar uma sonoridade ligada à beleza escondida sob a máscara, sua esposa, a bela loira Madelyn.

A orquestração das imagens na série de Lucybelle é a princípio a estrutura de um álbum comum, não fossem as presenças inquietantes das máscaras, o primeiro elemento que chama atenção. À medida que se detém nas imagens, porém, percebe-se uma forte estrutura poética e rítmica, referências literárias, musicais e filosóficas, que Meatyard fazia questão de amalgamar no cerne de suas criações.

Relacionando a primeira imagem com a última, tenho Meatyard e Madelyn, segundo Rhem (2002, p. 43), numa espécie de "jardim do Éden”. O casal (o fotógrafo e sua esposa/ Lucybelle), trocam suas identidades. Motivado por sua doença terminal e fragilizado, Meatyard faz essa troca de papéis e também incorpora Lucybelle como sua personagem. É muito importante notar que, se na primeira imagem do álbum Lucybelle pisa a mangueira (cobra) nesse "Éden" particular, como percebeu Rhem (2002), na última imagem, é vital perceber, que a árvore da vinha aparece com dupla ênfase, na imagem e na legenda. Imagem e legenda emolduradas por árvores de vinha. Por que essa ênfase? Por que Meatyard incluiu a árvore da vinha na última imagem? Intuo que ao vestir a máscara Lucybelle, que é a potência, a protagonista do poema, Meatyard enfatiza paradoxalmente a árvore da vinha e o vinho que remetem à vida e à juventude. Como aponta Durand (1997, p. 261), "O vinho é símbolo da vida escondida, da juventude triunfante e secreta”. Se a imagem derradeira do álbum traz o autor debilitado e perto do fim (ele morreria em 1972), a presença e a ênfase na árvore da vinha são sintomáticas do devir que Meatyard intuiu em seu uso da fotografia e da máscara como potências dessa série. Se me atrevo a aprofundar essa visão da máscara, numa espécie de reverso da fotografia, ultrapassam-se as camadas e a seriação, acompanhando uma movimentação que é do escopo da poesia. Vida, morte, a beleza dos pensamentos e das ideias constituem o foco dessa meditação sobre a vida em seus encontros, permeados pelo afeto, por meio do acontecimento fotográfico. Nesse álbum, 15 Meatyard trabalha

14 Segundo a pesquisa de Rhem (2000, p. 5), é importante notar que Meatyard era um leitor contumaz de poetas modernistas como Erza Pound e colecionava discos de jazz (possuía 1.500 discos), além de tocar accordeón.

15 É importante notar a respeito do projeto "Lucybelle", que ele se concretiza com a feitura e impressão de 
com a máscara que é ao mesmo tempo opaca, transparente e reflexiva; material e imaterial, síntese da própria fotografia.

\section{Conclusão}

Tanto o teatro como a fotografia evidenciam um jogo de aparências que enquadra o mundo e o transpõe, acessando por intermédio de sua poética, conteúdos e imagens, mediadas e construídas. Não é por acaso que a fotografia que contempla em seu repertório o campo da ficcão é chamada de fotografia encenada ou construída. Destaco uma singularidade na fotografia encenada que frequentemente escapa aos estudos teóricos: trata-se do gestual do fotógrafo imantado com os objetos de seu repertório particular.

Lugar da presença e da ausência, a fotografia é máscara perene que nos aponta o lugar do mistério, do duplo. Entre manifestações corpóreas e incorpóreas, o gesto fotográfico alcança o desejo de habitar as coisas. Na captura da ambiência fotográfica, o fotógrafo realiza seu desejo de habitar a própria cena fotografada. A fotografia seria então essa máscara, a camuflagem que dá curso a esse desejo?

\section{Referências}

AMARAL, A. M. O inverso das coisas. In: MORETTI, G. (ed.). Móin-Móin: Revista de Estudos sobre Teatro de Formas Animadas. Jaraguá do Sul: SCAR/UDESC, ano 1, v.1, 2005, p. 12-24.

https://doi.org/10.5965/2595034701012005012

BARTHES, R. A câmara clara. (Tradução: Manuela Torres). Lisboa: Edições 70, Ltda, 2012.

BAUDRILLARD, J. Simulacros e simulações. Lisboa: Relógio D’Água, 1991.

CHERMAYEFF.C. (ed.). Lilian Bassman. London: Bulfinch Press Book, 1997.

DUBOIS, P. 0 ato fotográfico e outros ensaios. São Paulo: Papirus, 1993.

DURAND, G. As estruturas antropológicas do imaginário. São Paulo: Martins Fontes, 1997.

um álbum-livro contendo as 64 imagens com legendas escritas à mão por Meatyard. 0 livro de Rhem (2002) reproduz as 64 imagens e lhes acrescenta um texto teórico e outras imagens do artista. Observei na pesquisa, que o álbum (livro de artista), como imaginado por Meatyard, não chegou a ser produzido nesses moldes. 
ESTÉS, P.C. Mulheres que correm com os lobos. Rio de Janeiro: Rocco, 1995.

FERNANDES, F.J. Imagens construídas, imagens desconstruídas. In: CHIODETTO, E. (org) A invenção de um mundo. São Paulo: Itaú Cultural, 2009, p.156-161.

KOSSOY, B. Viagem pelo fantástico. Site do autor, disponível em: http://boriskossoy.com/publicacao/ viagem-pelo-fantastico/. Acesso:10 janeiro 2021.

LISSOVSKY, M. A máquina de esperar: origem e estética da fotografia moderna. Rio de Janeiro: Mauad X, 2008.

OMAR, A. 0 zen e a arte gloriosa da fotografia. São Paulo: Cosac Naify, 2000.

O'CONNOR, F. Cuentos completos. Buenos Aires: Debolsillo: 2008.

PERSONA. Dicionário Priberam da Língua Portuguesa [online], 2008-2020. Disponível em https:// dicionario.priberam.org/persona. Acesso: 3 fev. 2021.

RHEM, J. Ralph Eugene Meatyard: The family album of Lucybelle Crater and other figurative photographs. New York: Distributed Art Publishers, 2002.

ROUILLÉ, A. A fotografia: entre documento e arte contemporânea. (Tradução: Constancia Egrejas). São Paulo: Editora Senac-SP, 2009.

SHERMAN, C. Instagram. Disponível em https://www.instagram.com/cindysherman/?hl=pt-br. Acesso: 5 fev.2021.

SIMÕES, C. Mamulengueiro é ator? In: MORETTI, G. (ed.). Móin-Móin: Revista de Estudos sobre Teatro de Formas Animadas. Jaraguá do Sul: SCAR/UDESC, ano 1, v.1, 2005, p. 119-146. https://doi.org/10.5965/2595034701012005118

SOBRINHO, T. Reflexões sobre o ator no teatro de imagens. In: MORETTI, G. (ed.). Móin-Móin: Revista de Estudos sobre Teatro de Formas Animadas. Jaraguá do Sul: SCAR/UDESC, ano 1, v.1, 2005, p. 79-104. https://doi.org/10.5965/2595034701012005079

SONTAG, S. Ensaios sobre fotografia. (Tradução: Joaquim Paiva), Rio de Janeiro: Arbor, 1981. 


\section{Sobre a autora}

América Cupello é fotógrafa, professora e pesquisadora independente. Pós-doutoranda no Programa de Pós-Graduação em Estudos Contemporâneos das Artes da Universidade Federal Fluminense. Doutora em Artes Visuais no programa de Pós-graduação da Universidade Federal do Rio de Janeiro. Mestre em Ciência da Arte pela Universidade Federal Fluminense. É jornalista (UFF). Principais publicações de suas fotografias: Revista Visionaire 41 World, New York, USA, 2003. Livro: Fotografia no Brasil: um olhar das origens ao contemporâneo, Funarte, 2004 e Revista Eletrônica Artscape, Japão, 2016. Contato: americacupello@gmail.com

LATTES: http://lattes.cnpq.br/0371779936195108

ORCID: https://orcid.org/0000-0003-2698-0054

Recebido em: 19-02-2021 / Aprovado em: 19-03-2021

\section{Como citar}

CUPELLO, America. (2021). Máscaras, ficção e mise-en-scène na fotografia contemporânea. Revista Estado da Arte, Uberlândia. v.2, n.1, p. 143-159, jan./jun. 2021. https://doi.10.14393/EdA-v2-n1-2021-59395 